$\left(\begin{array}{llll}\text { Jpn. } & \text { J. } & \text { Hosp. } & \text { Pharm. } \\ \hline \text { 22(1) } & 13 & \text { 棓 } & \text { 交 } \\ 19 & (1996)\end{array}\right)$

ポリアミノ酸による有機リン系殺虫剤および除草剤の吸着についての検討

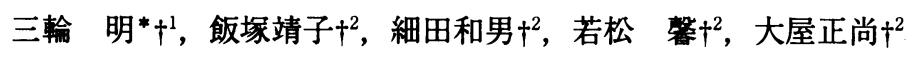

日高病院薬郕部 +1

群馬大学工学部生物化学工学科 ${ }^{2}$

\title{
Adsorption of Organic Posphorous Insecticides and Herbicides by Polyamino Acids
}

\author{
AKIRA MIWA ${ }^{*} \dagger^{1}$, YASUKO IIZUKA $\dagger^{2}$, KAZUO HOSODA $\dagger^{2}$, KAORI WAKAMATSU $\dagger^{2}$ and MASANAO OYA $\dagger^{2}$
}

Department of Pharmacy, Hidaka Hospital $\dagger^{1}$

Department of Biological Science, Faculty of Engineering, Gunma University $\dagger^{2}$

$$
\left(\begin{array}{l}
\text { Received May 17, } 1995 \\
\text { Accepted September 8, } 1995
\end{array}\right)
$$

Recently, it have been reported that many clinical cases have injested insecticides and herbicides either for the purpose of suicide or by mistake, and thet these agricaltural chemicals poison the soil, especially rivers or lakes. Removal of these compounds is thus needed. In this regard, we report herein the application of polyamino acids for the adsorption of these agricultural chemicals by using the quartz-crystal microbalance (QCM) method.

The homopolyamino acids exhigbit a high affinity to malathion. Poly (Leu) adsorbed an equal mass of cyanophos and trifluralin. Accordingly, polyamino acids are expected to be useful as adsorbents for organic phosphorous insecticides and herbicides.

Key words - quartz-cyrstal microbalance, polyamino acid, adsorption, organic phosphorous insecticides, herbicides

\section{緒言}

我々はポリアミノ酸が有機リン系殺虫剤をよく

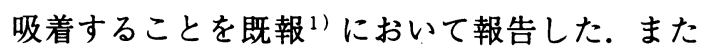

$\dagger^{1}$ 群馬県高崎市中尾町886;886, Nakao-machi, Takasaki-shi, Gunma, 370 Japan

$\dagger^{2}$ 群馬県桐生市天神町1-5-1;1-5-1, Tenjin-cho, Kiryu-shi, Gunma, 376 Japan ng 単位でリアルタイムに微量定量できる QuartzCrystal Microbalance (QCM) の方法 ${ }^{2-4)}$ を用いて, 農薬の吸着量を求めるとともに, 吸着平衡に達す るまでの時間も測定できることも明らかにし だ).

事故や自殺目的で農薬を服毒する症例は多く， その中でも有機リン系殺虫剤や除草剂を服毒する 症例は多い6). そこで有機リン系殺虫剤を用い, 
ポリアミノ酸に対する吸着量を検討することとし た．有機リン系殺虫剤としては，中毒症例の多い フェニトロチオン（商品名 スミチオン乳剂； 0 , 0-Dimethyl 0-4-nitro-m-toluyl phosphorothioate), またフェニトロチオンと化学構造が類似している イソキサチオン（商品名 カルホス乳剂；0,0diethyl 0-( 5-phenyl-3 -isoxazolyl) phosphorothioate), シアノホス（商品名 サイアノックス乳剤；0－ 4-cyanohenyl 0,0-dimethyl phosphorothioate)を用 いた。また除草剤としてはその化学構造にベンゼ ン環を有するジニトロアニリン系化合物のトリフ ルラリン（商品名 トレファノサイド乳剤 $; \alpha, \alpha$, $\alpha$-trifluoro-2, 6 -dinitro $\mathrm{N}, \mathrm{N}$-dipropyl- $\rho-$ toluidine）を用いた。これらはいずれもその化学 構造内にベンゼン環を有するため, 今回我々は有 機リン系殺虫剤でベンゼン環を有しないマラチオ ン(商品名 マラソン乳剤；0,0-dimethyl S-(1,2 -dicarbethoxyethyl) dithiophosphate) を用い, 吸着 率を比較検討した。

マラチオンは紫外部に吸収光を持たず，分光光 度計による定量はできなかったため, QCM 法に<smiles>COC(=S)Oc1ccc([N+](=O)[O-])c(C)c1</smiles>

Fenitorothion

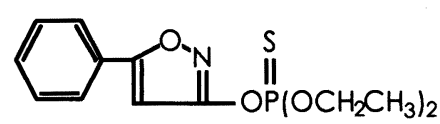

Isoxathion
より吸着率を測定した。

吸着剤として，フェニルアラニンとロイシン， フェニルアラニンとアラニン, ロイシンとアラニ ンの共重合体（以下それぞれ poly（Phe, Leu), poly (Phe, Ala), poly (Leu, Ala) と表記), また ロイシンと化学構造が類似しているバリンとアラ ニンの共重合体 (以下 poly（Val, Ala）と表記), 疎水性の脂肪族アミノ酸であるアラニン, ロイシ ンのホモポリマーを使用し，ポリアミノ酸の質量 に対する農薬の吸着量の割合を吸着率として求め た.

\section{実 験 方 法}

\section{1. 試料}

1) 農薬

フェニトロチオン（スミチオン乳剤, 八州化学 工業(侏)，イソキサチオン (カルホス乳剤, 三共 (侏)，シアノホス (サイアノックス乳剤, 三共(侏)， マラチオン (マラソン乳剤, (株アグロス), トリ フルラリン（トレファノサイド乳剤，塩野義製薬 (株)）を用いた（図1）。<smiles></smiles>

Cyanophos<smiles>CCCN(CCC)c1c([N+](=O)[O-])cc(C(F)(F)F)cc1[N+](=O)[O-]</smiles>

Trifluralin<smiles>CCOC(=O)C(CC(C)=P)C(=O)OCC</smiles>

Malathion

図 1. 農薬の化学構造式 


\section{2 ) 吸着剂}

ポリアミノ酸共重合体として, N-カルボキシー $\alpha$-アミノ酸無水物（NCA）を重合溶液中溶液重 合させ合成し，ホモポリマーとして poly（Ala）, poly（Leu）, 共重合体としてロイシンとアラニン が1：1である poly（Leu, Ala), フェニルアラ ニンとロイシンが1：2である poly（Phe, Leu), バリンとロイシンが1：1である poly（Val, Leu）を用いた，分子量は poly（Ala）が約5000, poly（Leu）が約 9000 , poly（Phe, Leu）は110000 であり，の共重合体は60000～70000であった。い ずれの共重合体もそれぞれのアミノ酸がランダム にペプチド結合している.

\section{2. 実験}

\section{1) 測定装置}

水晶発振子は, AT-cut, 基本共鳴周波数 9 [MHz](九州電通(侏))のものを用い，これを恒温槽 で温度コントロールされた各測定環境においた。 発振子は直流安定装置安定電源装置 (model GPR -1810, Good will instrument Co. ) で直流電流 5 [V] で駆動した．発振子の共鳴周波数は，共振回路と 同軸ケーブルで接続してある周波数測定装置 (model SC-7201, 岩通(怢) で測定し, GP-IB イ ンターフェイスボード (model PC-9801-29m, NEC) で接続したパーソナルコンピューター (model PC-9801Vm, NEC)に取り込んだ.

2 ) 測定方法

ポリアミノ酸をトリフルオロ酢酸とクロロホル ム $(1 ： 9)$ の混液に適当な濃度に溶かしておいた。 電極上に何も乗せていない水晶発振子の周波数 （F０）を測定し，次に溶かしたポリアミノ酸を シリンジで水晶発振子の電極上にのせ, 溶媒を完 全に飛ばした。このとき膜の重量が重すぎると農 薬を吸着した際，電極からはがれやすくなり測定 が不能となるので, 周波数（F1）を測定しなが ら調節した。

周波数の $1[\mathrm{~Hz}]$ の変化が電極上の質量変化約 $1 \mathrm{ng}$ に対応しているので,（F 0 ）から（F 1) を引いたものが，ポリマーの膜量に対応する. $37^{\circ} \mathrm{C}$ 恒温槽で温度コントロールされた容器（容 量 $14 \mathrm{ml} ） に$ 蒸留水を約 $13 \mathrm{ml}$ 入れておき,ポリアミ ノ酸の膜が付いた水晶発振子を容器内に入れた。 周波数が平衡状態に達したことを確認し周波数 （F2）を測定した.

次に農薬を $1 \mu \mathrm{M}$ 加えてポリマーが農薬を吸着 すると周波数は減少した. 再び平衡状態に達した ら，そこでの周波数(F 3)を測定した（F 2) と (F 3 )の差が農薬の吸着量に対応する. (F 0) と（F 1) の周波数の差に対する(F 2) と（F 3) の周波数の差の割合を吸着率（\%）として表した. また周波数は 1 秒ごとに測定できるので，農薬の 吸着平衡に達するまでの時間を測定した。

\section{結果}

表 1 にアミノ酸共重合体によるマラチオンの吸 着率および吸着平衡にいたるまでの時間を示した。 平均値を表に示し，誤差は土3.5\%だった。 $\mathrm{t}$-検 定により吸着率に有意差（p<0.05）が認められ た.

表 1.アミノ酸共重合体によるマラチオンの吸着率 および吸着平衡に至るまでの時間

\begin{tabular}{lcc}
\hline & 吸着率 (\%) & 時間 $(\mathrm{min})$ \\
\hline poly (Phe, Leu) & 34.1 & 5 \\
poly (Phe, Ala) & 50.6 & 4 \\
poly (Leu, Ala) & 43.1 & 7 \\
\hline
\end{tabular}

ポリアラニンによる農薬の吸着率の経時変化を 図 2 に,ポリロイシンによる農薬の吸着率の経時 変化を図 3 に, poly（Val，Ala）による農薬の吸 着率の経時変化について図 4 に, それぞれ示した。 Poly（Ala）による農薬の吸着率の経時変化にお いて，いずれの農薬においても最初の数分で吸着 率が上昇しはじめ，その後なだらかに上昇した。 シアノスの吸着率は高く, フェニトロチオンとイ ソキサチオンの吸着率はほほ同程度だった。しか しトリフルラリンの吸着率が一番小さい值を示し た.マラチオンの吸着率においてはいったん吸着 


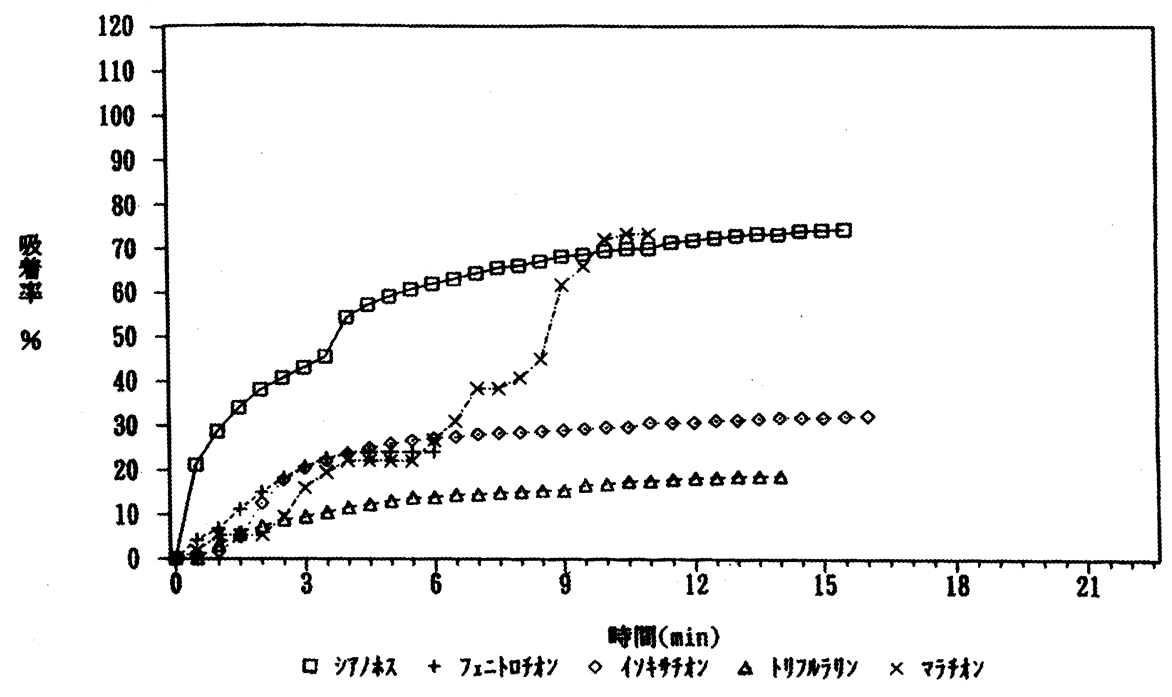

図 2.Poly（Ala）による農薬の吸着率（\%）

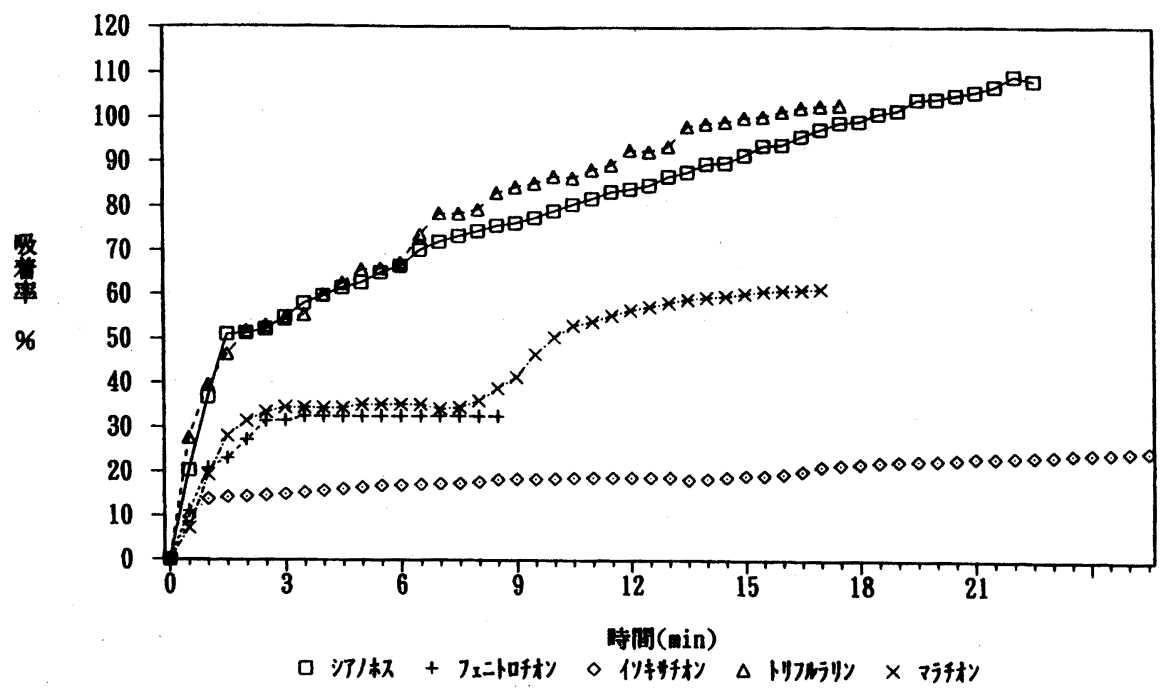

図 3．Poly（Leu）による農薬の吸着率（\%）

平衡に達した後再び吸着率が上昇し始め, その吸 着曲線は多段階を示した。

Poly（Leu）による農薬の吸着率の経時変化に おいて, いずれの農薬も吸着率は最初の 2 分くら いで高くなり，その後はなだらかに上がって入っ た. 一方シアノホスとトリフルラリンにおいては 吸着率は $100 \%$ を越え, ポリアミノ酸の膜質量以
上吸着した.フェニトロチオンとイソキサチオン の吸着率はほとんど同じであったが，フェニトロ チオンの方が吸着速度が速く, イソキサチオンの 吸着率は遅かった. マラチオンはいったん吸着率 が飽和に達した後再び上昇しはじめ, 吸着曲線が 二段階となった。

Poly（Val, Ala）による農薬の吸着率の経時変 


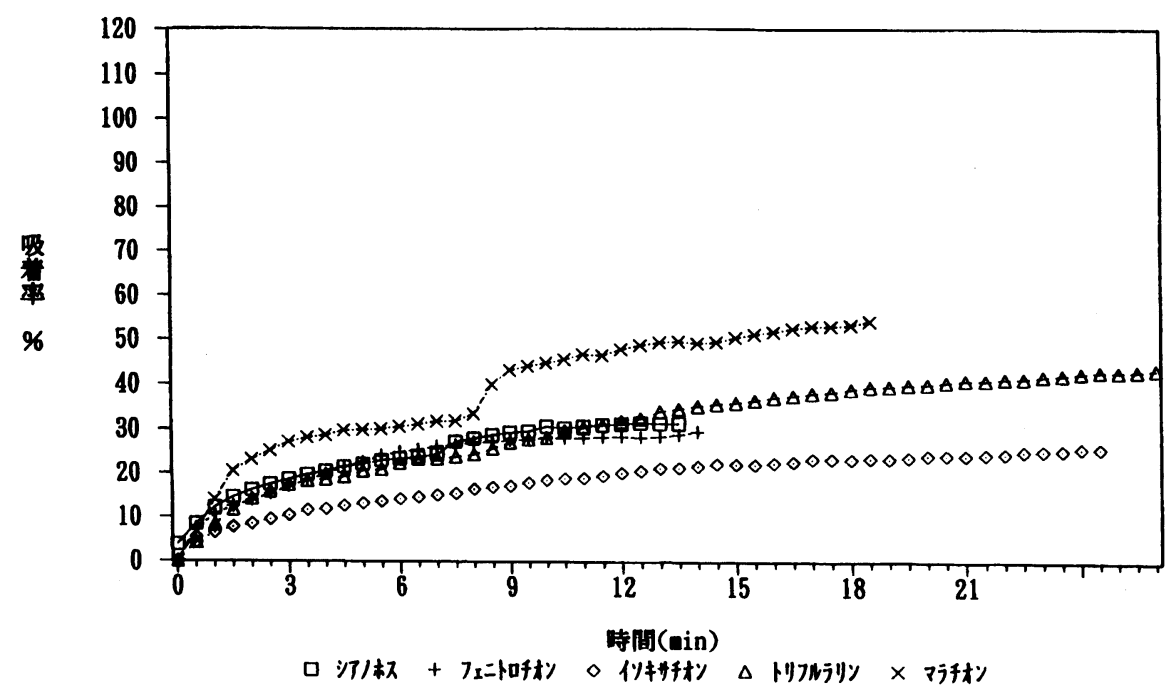

図 4.poly (Val, Ala) による農薬の吸着率

化において全体的に poly（Ala）や poly（Leu） よりも吸着率が低かった.フエニトロチオン, シ アノホス, トリフルラリンの吸着率はほほ同じく らいで，イソキサチオンの吸着率はそれらより若 干低かった. マラチオンの吸着率は一番高く, そ の吸着曲線は二段階であった. 表 $2 に$ にポリアミ ノ酸による農薬の吸着が飽和状態となったときの 吸着率を示した.平均値を表を示し,誤差は土3.7 \%だった， 2 元配置法 $\mathrm{t}$-検定により，農薬差， ポリアミノ酸差の 2 要因とも有意差 $(\mathrm{P}<0.05)$ が認められた. poly (Ala), poly（Leu）によるシ アノホス,マラチオンの吸着率は高く, poly (Leu), poly（Val, Ala) によるトリフルラリン の吸着率が高かった.また poly (Ala), poly (Leu)
によるシアノホス, マラチオンの吸着率が高く, poly（Leu）ではトリフルラリンの吸着率も高か った. poly（Val, Ala) ではマラチオン,トリフ ルラリンの吸着率が高かった.

\section{考察}

今回検討した有機リン系殺虫剂は, ジチオリン 酸部位の構造は類似しており，エステル結合して いる部位が, フェニトロチオン, シアノホス, イ ソキサチオンはベンゼン環を持つが, マラチオン はベンゼン環を持たない。また除草剤として用い たトリフルラリンはベンゼン環を持つ. 吸着剤と して使用したアミノ酸についても, poly（Phe, Leu), poly（Phe, Ala）のように芳香族アミノ酸

表 2.ポリアミノ酸による有機リン系殺虫郕および除草剤の吸着率（\%）

\begin{tabular}{lccc}
\hline & poly $(\mathrm{Ala})$ & poly $($ Leu $)$ & poly (Val, Ala) \\
\hline フェニトロチオン & 24.1 & 32.5 & 29.5 \\
シアノホス & 74.5 & 109.4 & 30.0 \\
イソキサチオン & 32.2 & 28.4 & 25.7 \\
マラチオン & 73.5 & 61.4 & 43.4 \\
トリフルラリン & 18.6 & 102.9 & 54.2 \\
\hline
\end{tabular}


を含む共重合体と，脂肪族アミノ酸のロイシン， アラニンのホモポリマーおよび poly（Val, Ala) において, QCM 法で吸着率を比較した。

Poly（Ala）による農薬の吸着において, シア ノホス, マラチオンの吸着率は高く, ほほ同じ值 であった．しかし吸着率の経時変化を比べると, 両者の吸着機構は異なっていると考えられる.す なわちシアノホスは時間経過とともに吸着してい き，やがて吸着率は一定となる。これはポリアミ ノ酸に吸着の座席（サイト）があるとすると， シ アノホスによりこの吸着の座席（サイト）が吸着 飽和に達し，それ以上吸着することができなくな ったためである.一方マラチオンは, いったん吸 着が平衡に達した後, 更に吸着率が増えている.

これはポリアミノ酸にマラチオンが吸着飽和にな った後, 吸着した第 1 層目のマラチオンの上に第 2 層目, 第 3 層目のマラチオンが吸着していくと いう，多分子層吸着をしていることを示している。 その他の農薬の吸着率は低く, 経時的な吸着率の 曲線はシアノホスと類似しており, 単分子層吸着 であることを示している。

Poly（Leu）によるシアノホス,トリフルラリ ンの吸着率は高く, ポリアミノ酸自身の質量以上 吸着した. シアノホスもトリフルラリンも最初の 2 分くらいまでは急に吸着率が増え，その後はゆ るやかに増えている。この 2 分以降の吸着につい ては，多分子層吸着をしていると考えられる．ま たマラチオンの吸着率は, 約30\%でいったん吸着 飽和となり 2 段階目は約 $60 \%$ で吸着飽和となって いることから，2 分子層吸着をしていることを示 している.

Poly（Val, Ala) による農薬の吸着率は poly (Ala) や poly（Leu）のような，農薬の種類に よる吸着率の差はあまり見られなかった。またマ ラチオンは poly（Leu）と同じように 2 分子層吸 着をしていることを示している.

Poly (Phe, Leu), poly (Phe, Ala), poly (Leu, Ala) によるマラチオンの吸着率では, poly（Phe, Ala）が他よりも若干高く, poly（Phe, Leu) が
低かった. poly（Val, Ala）と poly（Leu, Ala) とは化学構造が類似しているため, 吸着量もほほ 同じであった。しかし poly（Ala）や poly（Leu） などのホモポリアミノ酸も化学構造は類似してい るものと考えられるので, マラチオンの吸着率も 同じような値を示すものと予想された．しかし， ホモポリアミノ酸の方が, 共重合体よりも高かっ た. 共重合体は異なるアミノ酸がランダムにペプ チド結合しているため，側鎖に統一性がない。ア ミノ酸共重合体によるマラチオンの吸着率がホモ ポリアミノ酸より低いのは,このポリアミノ酸の 立体構造も関係していると考えられる。

フェニトロチオンとシアノホスの化学構造上の 相違点は，フェニル基に結合している置換基が異 なっているのみである. poly (Ala) p poly (Leu) では, フェニトロチオンとシアノホスの吸着率に おいて，著しい差が生じたことは，ポリアミノ酸 による農薬の吸着には, ポリアミノ酸の化学構造 や農薬の化学構造により影響されていることを示 している.

固一液界面における吸着は主として, van der waals 力, 疎水基同志の総合作用力, 親水基同志 の相互作用力, 静電引力, 水素結合, 共有結合の ような種々の力が多用に作用し合っている7). ポ リアミノ酸による農薬の吸着は，その吸着に選択 性があることから疎水基や親水基同志の相互作用 力が主に関与していると考えられる。

ポリアミノ酸を吸着剤として応用する場合, ア ミノ酸の組合せ，あるいは他のポリマーと共重合 させるなどの方法により，農薬の吸着に選択性を 持たせることも可能である．そしてその応用範囲 はフィルムにするなど成型も容易であり広い.

謝辞 本研究において御教示頂いた東京工業大学の 岡畑恵雄教授に感謝いたします。

\section{引用文献}

1) 三輪 明, 飯塚靖子, 若松 篃, 大屋正尚, 日 農化, 66, 1467-1473 (1992).

2) Yoshio Okahata and Katsuhiko Ariga, J. Chem. 
Soc., Chem. Commun, 1535-1537 (1987).

3 ) Yoshio Okahata, Kazuiko Kimura and Katsuhiko Ariga, J. Am. Chem, Soc., 111, 9190-9194 (1989).

4 ) Daniel A.Buttry and Michael D.Ward, Chem. Rev., 92, 1355-1379 (1992).
5) 病院薬学投稿中

6 ）䀿)日本中毒情報センター, 中毒研究，6，415418 (1993).

7 ) 岡部平八郎, “界面工学”, 共立出版, 東京, 1986, pp.62-63. 